\title{
Assessing the surface material quality of unpaved rural roads to understand susceptibility to surface deterioration. A case study of four rural areas in KwaZulu-Natal, South Africa
}

\author{
Lucky S'phumelele Nkomo, ${ }^{\mathrm{a}, *}$, Sumaiya Amod Desai ${ }^{\mathrm{a}}$, Khoboso Elizabeth Seutloali ${ }^{\mathrm{b}}$, \\ Kabir Yunus Peerbhay ${ }^{\mathrm{a}}$, Timothy Dube ${ }^{\mathrm{c}}$ \\ ${ }^{a}$ Discipline of Geography, School of Agric. Earth \& Environmental Sciences, University of KwaZulu Natal, Durban, South Africa \\ ${ }^{\mathrm{b}}$ Department of Geography and Environmental Science, National University of Lesotho, PO Roma 180, Lesotho \\ ${ }^{\mathrm{c}}$ Institute for Water Studies, Dept of Earth Sciences, University of the Western Cape, Private Bag X17, Bellville, 7535, South Africa
}

A R T I C L E I N F O

Keywords:

Road surface

Deterioration

Material selection

Unpaved roads

\begin{abstract}
A B S T R A C T
Road surface deterioration is one of the most common problems of unpaved road networks worldwide. It is a reduction in the performance of a road due to a decline in road surface material quality. Accumulated damage from vehicles, environmental and physical effects may contribute to a decline in the surface material quality and hence deterioration on an unpaved road surface. This study assesses the surface material quality of unpaved rural roads in four rural areas in the KwaZulu-Natal Province, South Africa in order to understand susceptibility to surface deterioration. The study further establishes other possible factors such as slope gradient and rainfall, that could determine the surface material quality. Soil samples were collected from R3, R4, and R5 road classes in four rural areas which are: Emazabekweni, Dukuza, Mkhunya and Mhlwazini Area. Laboratory analyses were conducted in order to determine the performance of the material as potential wearing course. Material performance was then determined using the Standard Methods of Testing Road Construction Materials (TMH 1:1976) classification method. The results obtained imply that there is a need for better material selection during the construction of unpaved road networks. All road classes in Mkhunya, Emazabekweni and Mhlwazini areas exhibited grading coefficient (Gc) values less than 16 and some of the shrinkage product (Sp) values in excess of 365 , corresponding to a classification of Class D, A and B. These results indicate material that is susceptible to slippery conditions, easily erodible and prone to the formation of ravels and corrugations. Correlation analysis results conducted to assess the individual relationship between measured rainfall and slope with field shrinkage product and grading coefficient values in each area indicated that variation in slope better explains shrinkage product values in each area with an $\mathrm{R}^{2}$ of 0.62 when compared to rainfall producing a lower $\mathrm{R}^{2}$ of 0.57 . For grading coefficient, slope and rainfall produced similar $\mathrm{R}^{2}$ of 0.65 and 0.67 , respectively.
\end{abstract}

\section{Introduction}

As the human population grows, additional infrastructure will be needed to support basic needs such as water, power, food, and healthcare. Meeting these needs generally requires the expansion of transportation networks. Roads form part of the primary assets or services that are required in order to sustain rural livelihoods (Bryceson, 2002; Njenga and Davis, 2003; Sati and Vangchhia, 2017). According to Plessis-Fraissard (2010:1), "rural roads have only relatively recently received attention in development research". Plessis-Fraissard (2010), argues that institutions such as the International Bank for Reconstruction and Development (IBRD), or World Bank (WB) only started addressing third world issues in the early 1960s on their development agenda. Prior to the 1960s, these institutions only focused on large structural infrastructure development needs, of which rural roads received very little attention as they were considered to be viewed as part of the agricultural sector. This sector that required investment was not seen as a priority. For instance, Lebo and Schelling (2001) indicate that in the late 1990s to early 2000s, approximately 900 million people in developing countries lived in rural areas that lacked reliable all-season roads and approximately 300 million lived in areas that were not accessible by any form of vehicle. Rural roads began to receive significant attention after the 1990s and institutions such as the International Forum of Rural Transport and Development (IFRTD) became influential

\footnotetext{
* Corresponding author.

E-mail address: NkomoS1@ukzn.ac.za (L.S. Nkomo).
} 
in providing support to the rural transport sector in developing countries throughout the world (Booth et al., 2000). In addition, the subSaharan Africa Transport Partnership (SSATP) program has played an important role in facilitating policy development in the roads sector within Africa (Porter, 2007). Despite the availability of rural policy in sub-Saharan Africa, road infrastructure investments and development continue to be at a very slow pace in most countries (Lufumpa et al., 2017; Adam et al., 2018; Calderon et al., 2018).

Studies conducted on roads in rural China show that investment into rural roads has a multiplier effect. These rural roads in China improve regional growth as they enable the movement of agricultural goods and non-agricultural goods and services between producers and markets in and out of communities (Shenggen and Zhang, 2004; Fan and ChanKang, 2005; Escobal and Ponce, 2008; Fan and Chan-Kang, 2008; Qin and Zhang, 2016). Similarly, studies conducted in rural India suggest that roads provide millions of rural people with access to services such as education, health, markets and as well as facilitate agricultural growth (Patel, 1984; Hazell and Haggblade, 1990; Kesterton et al., 2010; Asher and Novosad, 2016). Plessis-Fraissard (2010) indicates that $31 \%$ of the world's rural population live in areas that are isolated from markets and services. This population lives more than $2 \mathrm{~km}$ from an allseason road. An all-season road refers to a road that is drivable at all times of the year (Chambers et al., 1981). According to Porter (2002), all-season roads are crucial for rural economic development because they facilitate the movement of labour between residence and workplace.

Inaccessible rural areas become highly vulnerable to poverty and diseases (Wagstaff et al., 2004; Dercon, 2006). For example, a study conducted in Liberia on rural vulnerability to the Ebola Virus Disease (EVD), shows that inadequate health and transportation infrastructure contribute to the challenge of managing the disease outbreak in West Africa (Stanturf et al., 2015). Stanturf et al. (2015), argue that most rural road networks in Liberia were largely inaccessible in the rainy season and this caused delays in treatment, resulting in increased fatalities in affected regions. According to Riverson and Carapetis (1991) and Teravaninthorn and Raballand (2009), poor rural road conditions result in high transport costs and deficient transport services. In remote rural areas, bad road conditions contribute to costly access to markets. Porter (2014) argues that bad rural roads in remote areas hinder agriculture growth because any delays in the transportation of produce to markets, negatively affects farmgate prices. Good farmgate prices are influenced by the quality of the produce and as well as the sellers arrival time to the market (Jacoby, 2000; Asher and Novosad, 2016). Hence, good rural roads in remote areas are crucial when transporting perishable produce in order to reduce spoils while they are in transit, thus ensuring better market value for produce. Hettige (2006) argues that bad rural roads in remote areas contribute to poor transporter competition. The absence of transporter competition is seen as a key component of high transport fares in remote rural areas. However, Porter (2014) suggests that transporter competition in remote rural areas may rise only when the road network conditions are able to provide all-weather access.

Performance of gravel road surfaces is mostly affected by roadbed material quality, which is predominantly determined by factors such as surface deterioration amongst others. Surface deterioration is one of the most common problems of unpaved road networks worldwide (Jones, 1984; Wilkie et al., 2000; Porter, 2002; Fu et al., 2010). Unpaved roads usually consist of a graded and compacted surface, which is topped with hard surface material such as gravel or crushed rock that is mostly created from parent material present at that location. Parent material refers to the original geological material, which is also known as bedrock (Buol et al., 2011). The term surface deterioration in this study refers to a reduction in the performanceof a road due to a decline in road surface quality. Some of the most commonly prominent features of surface deterioration on unpaved roads include distresses such as potholes, rutting, erosion channels, dust, corrugations, loose material and stoniness. Unpaved roads in regions of steep terrain degrade rapidly, are rarely repaired properly, and often go without maintenance or the application of known best practices to mitigate erosion (Sidle and Ziegler, 2012). Surface deterioration on unpaved roads affects a number of environmental metrics, which include water quality, aquatic habitat, surface erosion, soil loss, and slope stability (Fu et al., 2010). For examples, Wemple et al. (2018) argue that surface deterioration of unpaved roads poorly affects the water quality of streams due to associated sediment runoff and road-related contaminants. Wemple et al. (2018) argument is supported by previous studies (Luce and Cundy, 1994; Ramos-Scharrón and MacDonald, 2005, 2007a; Ziegler and Giambelluca, 1997; Ziegler et al., 2001a; Ziegler et al., 2007) which indicate that unpaved forests or rural roads have the propensity to generate erosion-producing overland flow during most rainy events. Similarly, Trombulak and Frissell (2000) concluded that ecological effects of roads are associated with negative impacts on biotic integrity in both terrestrial and aquatic ecosystem. In any setting, tropical or temperate, the volume of sediment produced by a forest or unpaved road depends on the erodibility of the road surface (Ziegler and Giambelluca, 1997), sediment supply (Croke and Hairsine, 2006), traffic levels (Goosem, 2007), the drainage system in place (Lugo and Gucinski, 2000), maintenance (Gucinski, 2001), road geometry (Sessions, 2007), surfacing, soil properties (Croke and Hairsine, 2006), nearby vegetation cover (Coffin, 2007), as well as the magnitude and frequency of precipitation events (Ziegler and Giambelluca, 1997).

Road surface quality is determined by factors such as surface material quality amongst others. Material quality is reflected by aggregate durability as a wearing course, of which this is primarily defined by the aggregate's mechanical and chemical properties. Paige-Green (1989) argues that universally, there is no standardised method used for designing wearing courses for unpaved roads. According to Jones (1999) and Jones and Paige-Green (2015), a number of specifications exist for selecting materials for unpaved roads, but the common challenge is that their basis is often unclear. However, Paige-Green and Netterberg (1987) state that materials used for construction of unpaved roads must comply with the basic engineering properties. In addition, Paige-Green maintains that all wearing course material must contain the following key characteristics, "have sufficient cohesion to resist ravelling and erosion; have a particle size distribution that facilitates a tight interlock of the individual material particles, and have sufficient strength to support the applied traffic loads without significant plastic deformation." (Paige-Green, 2006:1). Paige-Green (2006) argues that using surface material with deficiencies in any of the aforementioned characteristics adversely affects material performance and this result in poor riding quality, increased maintenance and as well as an increased road surface material loss. Hence, Paige-Green (2006) established a chart (using material plasticity and grading properties) that classifies the expected performances of unsealed wearing course material (as seen on Fig. 2).

Paige-Greens (2006) chart has been widely used to classify material performance of unsealed roads in many countries worldwide. For example, a recent study was conducted in New Zealand (using PaigeGreen's material performance chart) to test and validate the charts applicability in determining expected material performance (Henning et al., 2015). The study was conducted on unsealed roads in Whangarei and Central Otago Districts. These two districts were selected because they represent the extreme climate geology and topographies of New Zealand. A number of samples were collected on different unsealed road networks for analysis. The attained findings were able to validate the applicability of Paige-Green's material performance chart because the nature of surface deterioration that was visually observed on the roads (in both districts), matched the expected material behaviour as classified on the chart. Therefore, good material selection is necessary when constructing unpaved roads because it can help enhance surface performance and reduce surface deterioration. Furniss et al. (1991) and Madzikigwa (2003) argue that it is not easy to fully assess the causes of surface deterioration on unpaved roads without understanding the 
physical, environmental and anthropogenic factors at interplay. On the one hand, physical factors include the road engineering components (such as design or alignment), traffic (such as vehicle volumes and sizes) and road surface material. On the other hand, environmental and anthropogenic factors include climate conditions, the surrounding landscape (such as vegetation cover, underlying geology and terrain) and maintenance conditions (Paige-Green, 1999a, b). In light of the aforementioned, research indicates that there have been very limited studies conducted to assess the contribution of environmental and physical factors on surface deterioration of unpaved roads (Alzubaidi and Magnusson, 2002; Leung and Marion, 1996). Plethora of research available has focused on issues around maintenance materials and dust binding methods (Gillies et al., 1999; Jones, 1999). Few studies have examined the effects of the surrounding landscape, climate conditions and the influence of geological properties because these factors cannot be affected by regular maintenance (Hartley, 1974; Keller and Sherar, 2003; Jones and Paige-Green, 2015). It is therefore crucial to identify and assess environmental forces which could have an impact on road surface in relation to material performance. For instance, Mwaipungu and Allopi (2012) indicate that unsealed road surfaces are directly exposed to environmental factors such as rainfall, wind and terrain, which influence the performance of gravel roads.

Unpaved road networks play an important role in the socioeconomic sector of South Africa, particularly in rural areas (Starkey, 2002; Njenga and Davis, 2003; Button, 2010). A study by Smith and Visser (2001) and Lishman (2013) shows that rural networks in South Africa consist of $301000 \mathrm{~km}$ of gravel and $63000 \mathrm{~km}$ of surfaced (paved) roads. In the province KwaZulu-Natal, gravel roads account for approximately 80 percent of the total of roads (Balaram and Mostert, 2014). These statistics provide a good indication of the value and services of unpaved road networks to rural areas and the need for their improvement in quality due to the constant deteriorating conditions experienced (Paige-Green, 2006). In most of sub-Sahara Africa, including South Africa, road deterioration could affect the livelihoods of rural communities thus road agencies need to find methods of evaluating the performance of road surface material, which can be used to assist in determining deterioration. In addition, this knowledge could be used in guiding proper maintenance programs for unpaved road surface material. This study therefore seeks to assess the surface material quality of unpaved rural roads in four rural areas in the KwaZuluNatal in order to understand susceptibility to surface deterioration. This study further establishes other possible factors (such as slope gradient and rainfall) that could determine road surface deterioration.

\section{Materials and methods}

This study was conducted in four rural areas namely, Emazabekweni, Dukuza, Mkhunya and Mhlwazini within the province of KwaZulu-Natal (KZN) (Fig. 1). Due to the understanding that KZN has a large geographical area, the areas under study were selected to represent the variation in microclimate and geological conditions of the province. Emazabekweni ( $30^{\circ} 15^{\prime} 5,52^{\prime \prime} \mathrm{S}$ and $\left.30^{\circ} 6^{\prime} 9,33^{\prime \prime} \mathrm{E}\right)$ and Mkhunya $\left(30^{\circ} 9^{\prime} 1,46^{\prime \prime} \mathrm{S}\right.$ and $\left.30^{\circ} 26^{\prime} 29,44^{\prime \prime} \mathrm{E}\right)$ are situated in the south-western while Mhlwazini $\left(28^{\circ} 56^{\prime} 18,60^{\prime \prime} \mathrm{S}\right.$ and $\left.29^{\circ} 17^{\prime} 46,86^{\prime \prime} \mathrm{E}\right)$ and Dukuza $\left(28^{\circ} 45^{\prime} 55,51^{\prime \prime} \mathrm{S}\right.$ and $\left.29^{\circ} 11^{\prime} 49,94^{\prime \prime} \mathrm{E}\right)$ are located in the north-western part of the province. KZN is the second largest populated province in South Africa, with approximately 11.5 million people in an area of $94,361 \mathrm{~km}^{2}$ (Stats SA, 2018). The 2013 report on Informal Settlement Status in KZN indicates that $46 \%$ of the population live on tribal land, while $47 \%$ in urban areas and the remaining $7 \%$ on private farms (Housing Development Agency, 2013). Out of nine provinces, KZN is ranked the third poorest region in South Africa based on gross domestic product per capita statistics (Ozler and Hoogeveen, 2005; Kepe and Tessaro, 2014; Musemwa et al., 2015). Huge backlogs in transport infrastructure in terms of maintenance and construction needs are regarded as one of the primary causes of high levels of poverty vested in the province (Kepe and Tessaro, 2014; Musemwa et al., 2015). Road statistics provided by the KZN Provincial Department of Transport indicate that in $2005,52 \%$ of the total road network conditions in the province were classified as "poor to very poor" and only $17 \%$ were in a "good to very good" condition. In reviewing the available literature and government databases, it has been established that there are no up-todate studies conducted which are reporting on the conditions of roads in KZN Province particularly in the last decade.

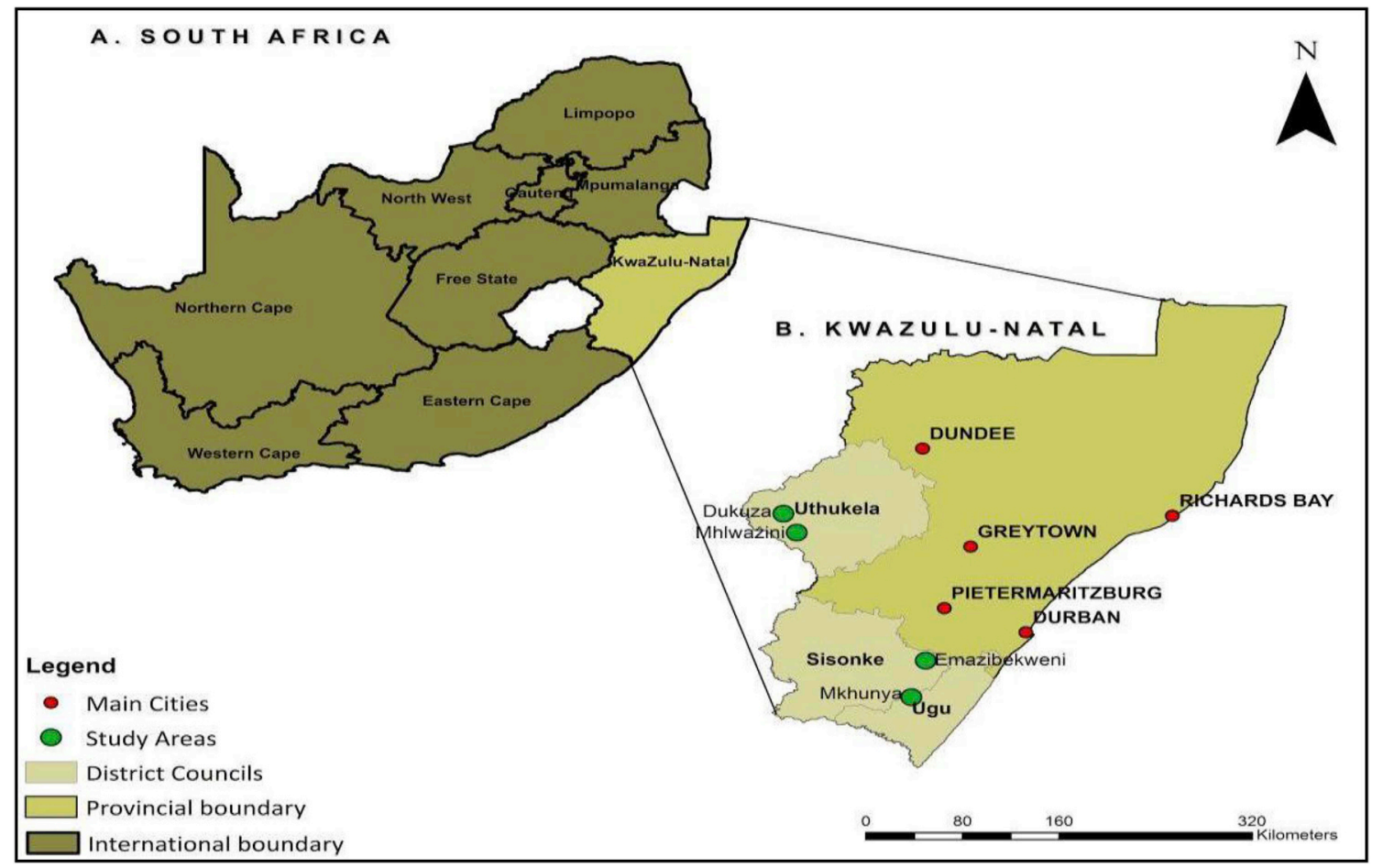

Fig. 1. Map showing the location of the four rural areas under study. 


\subsection{Identification of unpaved road networks}

Road networks of interest were identified by first traversing the selected areas using recent high resolution Google Earth imagery. Following this procedure, transect walks were done in each area in order to identify the road networks. A total of 11 unpaved roads were selected for this study. The road classes were: minor road (R3), collector road (R4) and local road (R5) selected based on the South African Road Classification and Access Management Manual, version 1.0 of August 2012 (Committee of Transport Officials, 2012). Due to the focus of this study, principal arterials (R1), major arterials (R2) and walkways (R6) road classes were not assessed.

\subsection{Collection of soil samples}

A hand held Global Positioning System (GPS) was used to record the location of each sampling point. In the areas under study, the total length of each road class was divided into sixteen equal intervals and samples were collected at every interval from the starting point. For example, the total road length of the R3 road class in Emazabekweni area is $20 \mathrm{~km}$, sixteen equal sampling intervals of $1.2 \mathrm{~km}$ were utilised. This rationale was applied to all sampled road classes, in order to collect samples that were representative of the entire road class. Ultimately, a total of 16 soil samples were collected (composited) from each road class (R3, R4 and R5). The area of Mhlwazini did not have the R3 road class, so samples were only taken for the R4 and R5 road classes. During the field sampling, a hand auger was used to retrieve $1-1.5 \mathrm{~kg}$ of material from the middle of the road at every interval. This material was placed into a plastic sampling bag and then sealed. This sampling procedure was repeated for all road classes and across all 4 of the study sites. All the sampled material was then transported to a laboratory for subsequent analysis.

\subsection{Methods utilised for material testing}

Key material properties influencing unpaved road performance include the grading or particle size distribution, the fines content, the clay content, and the material shear strength. These are determined from basic material indicator tests including a grading analysis, plasticity test (Atterberg Limits or bar linear shrinkage), and strength test. A grading analysis was done using the ASTM C136 standard test procedure (ASTM, 2006). This test method is used primarily to determine the grading of materials proposed for use as aggregates or being used as aggregates. The results are used to determine compliance of the particle size distribution with applicable specification requirements and to provide necessary data for control of the production of various aggregate products and mixtures containing aggregates. Accurate determination of material finer than the 75- $\mu \mathrm{m}$ (No. 200) sieve cannot be achieved by use of this test method alone. Therefore, Test Method C117 for material finer than $75-\mu \mathrm{m}$ sieve by washing was employed. Plasticity tests were derived from Atterberg limits results, which were performed using the AASHTO T 89 and T 90 laboratory specification (AASHTO, 2007; AASHTO, 2010). Atterberg limits are simple tests to determine the moisture contents of a material at which the material moves from a solid to a semi-solid, to a plastic and to a liquid state. The California bearing ratio (CBR) penetration tests were conducted to determine the mechanical strength of sampled material (Moloisane and Visser, 2014).

\subsection{Assessing road surface material performance}

The surface material quality of the unpaved roads was assessed by determining the material performance using the Standard Methods of Testing Road Construction Materials TMH 1 classification method (CSRA, 1976). This included particle size distribution analysis of sand, silt and clay soil particles. Atterberg Limits (namely liquid limit, plasticity index and linear shrinkage) were also assessed as they are useful in providing basic measure of the critical water content in fine-grained soils (Jones and Jefferson, 2012). The related shrinkage product (Sp) and grading coefficient (Gc) were then determined from the results of soil particle analysis and Atterberg limits according to Technical Methods for Highways report number 1 (CSRA, 1976). Provided below are the recommended material specifications for unpaved/unsealed roads suited for South African conditions (Paige-Green, 2007b).

$\begin{array}{ll}\text { Maximum size } & 37.5 \mathrm{~mm} \\ \text { Max oversize index } & 5 \% \\ \text { Shrinkage product (SP) } & 100-365(240) \\ \text { Grading coefficient (Gc) } & 16-34 \\ \text { Min CBR (\%) } & 15 \text { at } 95 \% \text { Mod AASHTO } \\ \text { Treton Impact value (\%) } & 20-65\end{array}$

$\mathrm{Sp}$ - Weighted bar linear shrinkage (P40 x BLS) and Gc - (P26.5 - P2)*P4.75/ 100 .

According to Paige-Green (2007b), the above specifications standards enhance unpaved road material performance. In this study, material performance was assigned using specifications adopted from the Technical Recommendations for Highways report number 20 (TRH20, 1990), which provides technical support to structural design, construction and maintenance of unpaved roads in South Africa (Fig. 2). This system utilises $\mathrm{Sp}$ and Gc to assign performance. The zones in Fig. 2 (namely zone A - E) are described in TRH20 (1990) as shown in Table 1.

\subsection{Rainfall and slope gradient data}

Rainfall and slope gradient data were determined in order to establish the environmental factors that could affect road surface deterioration under the given road surface material performance. Rainfall data of the study areas, with a spatial resolution of $1 \mathrm{~km} \times 1 \mathrm{~km}$, was derived from World Bioclim dataset (Hijmans et al., 2005). Topographic data (i.e. slope gradient) for each sampling area was obtained from the Shuttle Radar Topography Mission (SRTM) (Farr and Kobrick, 2000). Rainfall data was obtained from South African Weather Service (SAWS). This study utilised annual datasets obtained for a period of 37 years from 1980 to 2017. The data from SAWS was retrieved from local weather stations in close proximity to the communities, namely; Cathedral Peak-Hotel, Bergville-Mag, Weza-Plantations and Sawoti. Subsequently, the field sample points collected within each road class, were then used to extract Bioclim and topographic data using the zonal statistics tool in ArcGIS 10.4 software and utilised in the prediction of road deterioration.

\subsection{Determining the relationship between local variables and road surface material quality}

The relationship between environmental variables (i.e. slope gradient and rainfall) and the laboratory results of Sp and Gc was determined using simple linear regression, and the coefficient of determination $\left(\mathrm{R}^{2}\right)$ was derived.

\section{Results}

The findings of this study only provide results, which were obtained from an investigation conducted to assess surface material quality on unpaved rural roads in order to understand their susceptibility to surface deterioration. A study by Nkomo et al. (2016) was recently conducted using visual observation and field-based measurements in order to assess the type, severity and extent of surface deterioration on the road classes, which were investigated in this research paper. The findings of this current paper forms part of the follow-up research conducted by Nkomo et al. (2016). 


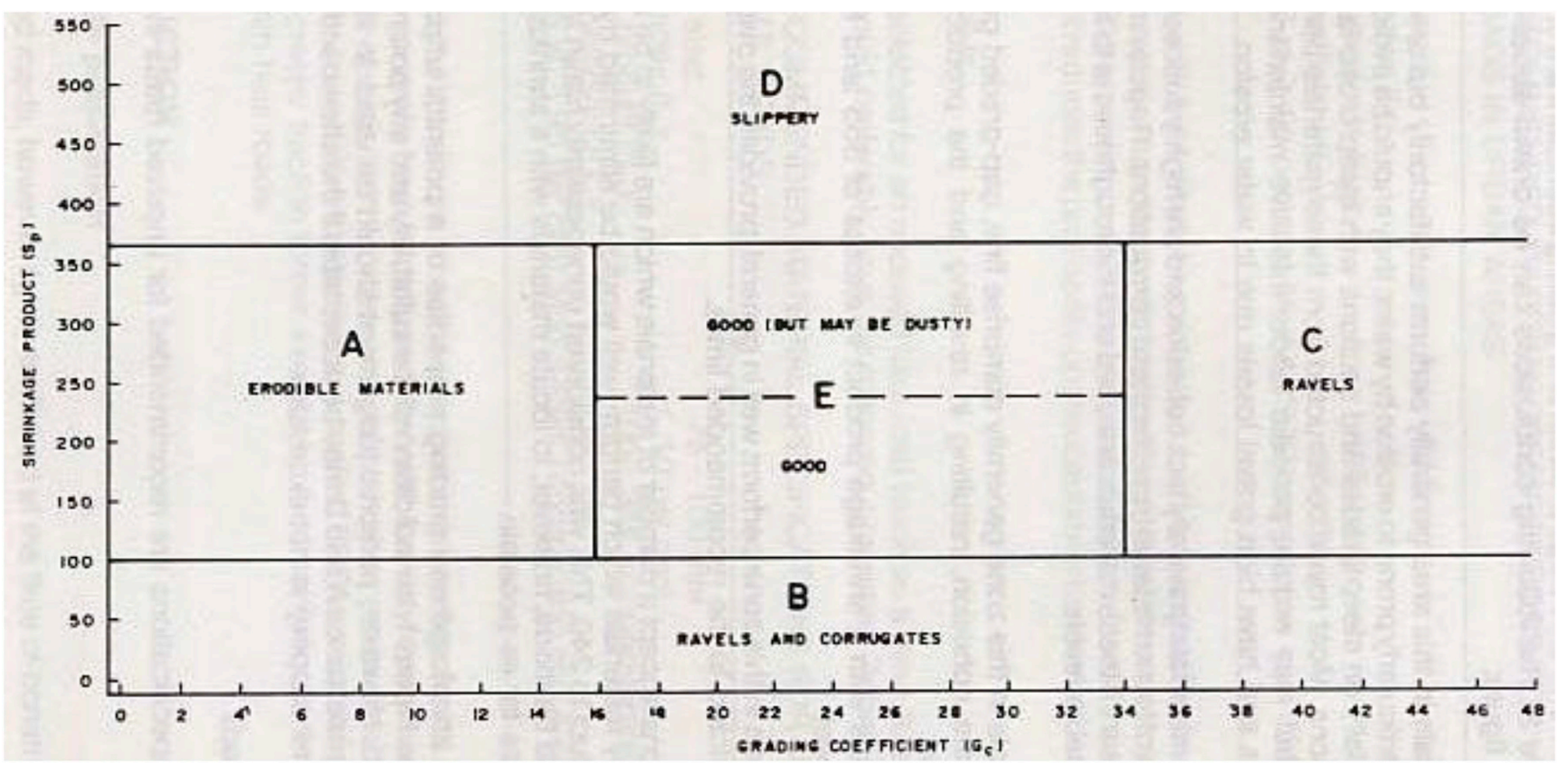

Fig. 2. Relationship between shrinkage product, grading coefficient and performance of unpaved wearing course gravels. (Adapted from TRH20, 1990).

Table 1

Description of zones and their expected performance characteristics (adapted from TRH20, 1990).

\begin{tabular}{|c|c|}
\hline Symbol & Description \\
\hline A & $\begin{array}{l}\text { Materials in this area generally perform satisfactorily but are finely graded and particularly prone to erosion by water: they should be avoided if possible, especially on } \\
\text { steep grades and sections with steep cross-falls and super-elevations. Most roads constructed from these materials perform satisfactorily but may require periodic } \\
\text { labour-intensive maintenance over short lengths and have high gravel losses due to water erosion. }\end{array}$ \\
\hline B & $\begin{array}{l}\text { These materials generally lack cohesion and are highly susceptible to the formation of loose material (ravelling) and corrugations. Regular maintenance is necessary if } \\
\text { these materials are used and the roughness is to be restricted to reasonable levels. }\end{array}$ \\
\hline $\mathrm{C}$ & Materials in this zone generally comprise fine, gap-graded gravels lacking adequate cohesion, resulting in ravelling and the production of loose material. \\
\hline D & Materials with a shrinkage product in excess of 365 tend to be slippery when wet. \\
\hline E & Materials in this zone perform well in general, provided the oversize material is restricted to the recommended limits \\
\hline
\end{tabular}

\subsection{Road surface material performance classification}

The results showing the location of each road class, in terms of shrinkage product and grading coefficient, for the four study sites has been shown in Fig. 3. From this figure, it can be observed that the R3 and R4 roads in Emazabekweni and Mkhunya lie within zone D. These are characterised by $\mathrm{Sp}$ values ranging from 400 to 600 and Gc values between 4 and 24. The results further show that R5 roads for the two study areas fall within zone A which is characterised by $\mathrm{Sp}$ values ranging from 300 to 450 and Gc values between 6 and 14. Therefore, these results indicate that R3 and R4 roads exhibit slippery conditions while R5 is characterised by erodible road surface material. The results indicate that the studied roads in Mhlwazini and Dukuza lie within zone $\mathrm{B}$ and $\mathrm{E}$, respectively. The roads that fall within Zone $\mathrm{B}$ are characterised by ravels and corrugates, while Zone E roads exhibit good road conditions that may be dusty.

\subsection{The environmental variables}

Fig. 4 displays rainfall data for the selected study sites for a period of 37 years from 1980 to 2017. It can be observed that Mhlwazini exhibit the highest maximum, minimum, and mean annual rainfall. The areas Mkhunya and Mazabekweni have the lowest maximum rainfall. The amount of rainfall recorded for Emazabekweni, Mkhunya and Dukuza is not significantly different. The slope gradient of the study sites are shown in Fig. 5. Fig. 6 shows the relationship between these environmental variables (i.e slope and rainfall) and shrinkage product and grading coefficient.

It can be noted that there is a linear relationship between environmental variables and Shrinkage product as well as grading coefficient. For instance, a positive relationship $\left(R^{2}=0.62\right)$ and $\left(\mathrm{R}^{2}=0.57\right)$ was found between shrinkage product and slope gradient as well as between shrinkage product and rainfall respectively. Similarly, an $\mathrm{R}^{2}$ value of 0.65 and 0.67 were obtained for the relationship between grading coefficient and both the slope gradient and rainfall, respectively. This suggests that both the shrinkage product and grading coefficient increase with the increase in slope gradient and rainfall.

\section{Discussion}

The obtained values of Sp generally do not fall within the recommended material specifications for unpaved rural roads in South Africa Other possible factors (such as slope gradient and rainfall) that could determine road surface deterioration were evaluated. Literature has already indicated that there is a need to understand the role of material quality in influencing deterioration of unpaved roads. Equally important is the selection of quality material for the construction of unpaved roads thus reducing surface deterioration and maintenance costs (Hodges et al., 1975; Paige-Green, 2007a; Mwaipungu and Allopi, 2012). This study shows that road classes in Mkhunya, Emazabekweni and Mhlwazini areas have poor material quality when compared to road classes in Dukuza area. All road classes in Mkhunya and Mhlwazini areas exhibited Gc values less than 16 and some of the Sp values in 

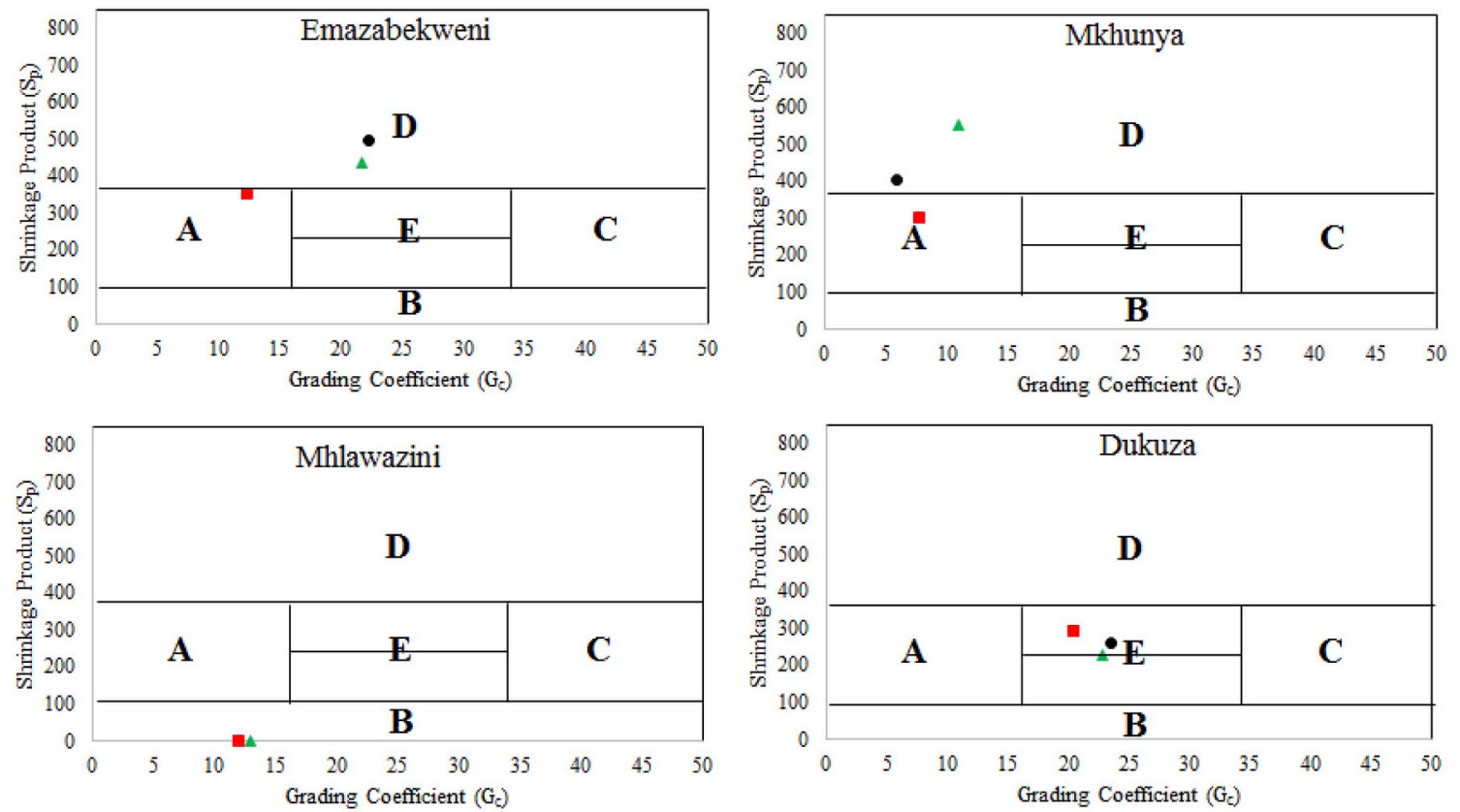

Key: $\bullet$ R3 $\triangle$ R4 $\backsim$ R5

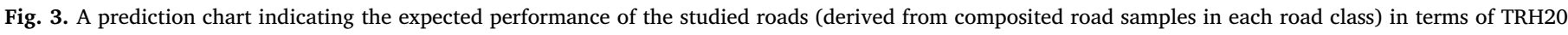
performance guidelines.

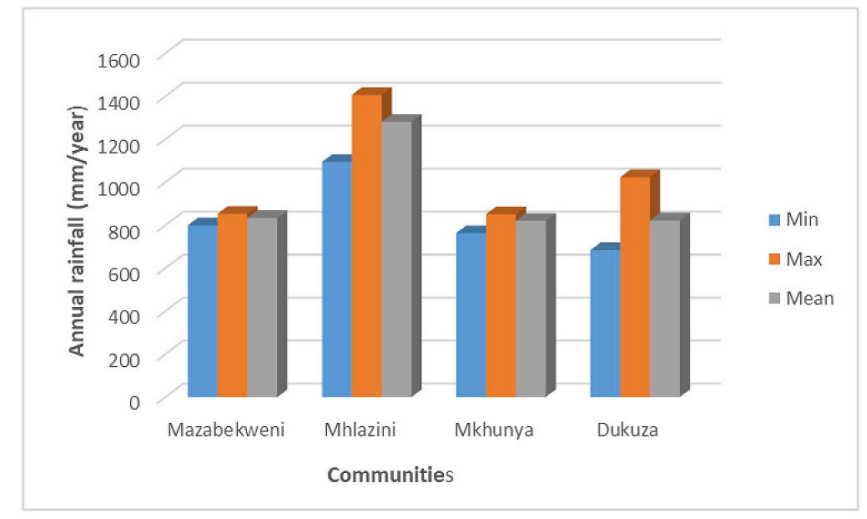

Fig. 4. The total rainfall on an annual basis for 1980-2017 for the communities understudy. (South African Weather Service, 2017).

excess of 365, corresponding to a classification of Class D, A and B. This indicates susceptibility to slippery conditions, erodible material and the formation of ravels and corrugations. This could result in a rapid deterioration of the surface area of the unpaved road hence affecting its use by the rural communities. Mwaipungu and Allopi (2012) indicated that these are typical road surface distress that influence road surface deterioration.

As argued by Queiroz and Gautam (1992), resource-limited regions do not have the capacity and economic means to acquire the best material quality for the construction of their unpaved roads thus they depend largely on using material that exists within their areas. The findings of this study are comparable with this argument because the soil properties of the sampled road material in each road network indicated strong similarities with the characteristics of the geological material that exists in each area. For example, all the areas under study are located in the regions characterised by the Karoo Supergroup (Ecca and Beaufort) geological formations, which are dominated by soils that consist of shale, mudstones and sandstones (Mucina and Rutherford, 2006). The high percentage of mudstone, shale and sandstone particles found in the sampled material from all road classes in Emazabekweni,
Mhlwazini and Mkhunya areas provided evidence that these road networks were constructed using local material and the nature of their surface deterioration shows consistent conditions. These conditions further challenge the mobility of residents in the short-term within these areas but also impacts on the long-term lifespan of the roads overall condition. Unpaved roads are semi-permeant infrastructures that are meant to last for many years depending on the nature of their maintenance. However, results of this study also show that material selection, slope and rainfall variability plays a major role in influencing the nature of surface deterioration and the lifespan of unpaved road networks.

The high annual rainfall received in Mkhunya and Mhlwazini areas (such as $819.7 \mathrm{~mm}$ and $1280.9 \mathrm{~mm}$ respectively) could further influence the deterioration of road classes in addition to the poor material quality in this area. Similarly, steeper slopes could further play an important role in the rate and extent of surface deterioration. It has already been indicated by previous research that there exists a linear correlation between the slope steepness and the level of soil erosion (Kachouri et al., 2015). An increase in slope gradient is associated with a significant increase in the amount of soil loss. These areas will potentially have higher maintenance costs. Although the results also emphasise that the road classes in Emazabekweni area have poor surface material, the rate and extent of deterioration could be less than that of Mkhunya and Mhlwazini areas where the slopes are steeper. Hence, selecting good surfacing material will be crucial in reducing the rate and extent of deterioration, especially in areas that have steep slopes and moderately to high annual rainfall.

Roads in the Dukuza area display good material quality, exhibiting Sp values between 100 and 365 and Gc values between 16 and 34, similar to those recommended by Paige-Green, 1999a, b, 2007a. The material quality in all the road classes in this area corresponded to a classification of class E, indicating good material, which can sometimes be dusty. Even though this area receives moderately to high annual rainfall $(822.0 \mathrm{~mm})$, the level of surface deterioration is minimal. This may be due to the combination of the gentle terrain and the road classes have good material quality. As argued by Hodges et al. (1975), PaigeGreen (2007b), and Mwaipungu and Allopi (2012) good material 


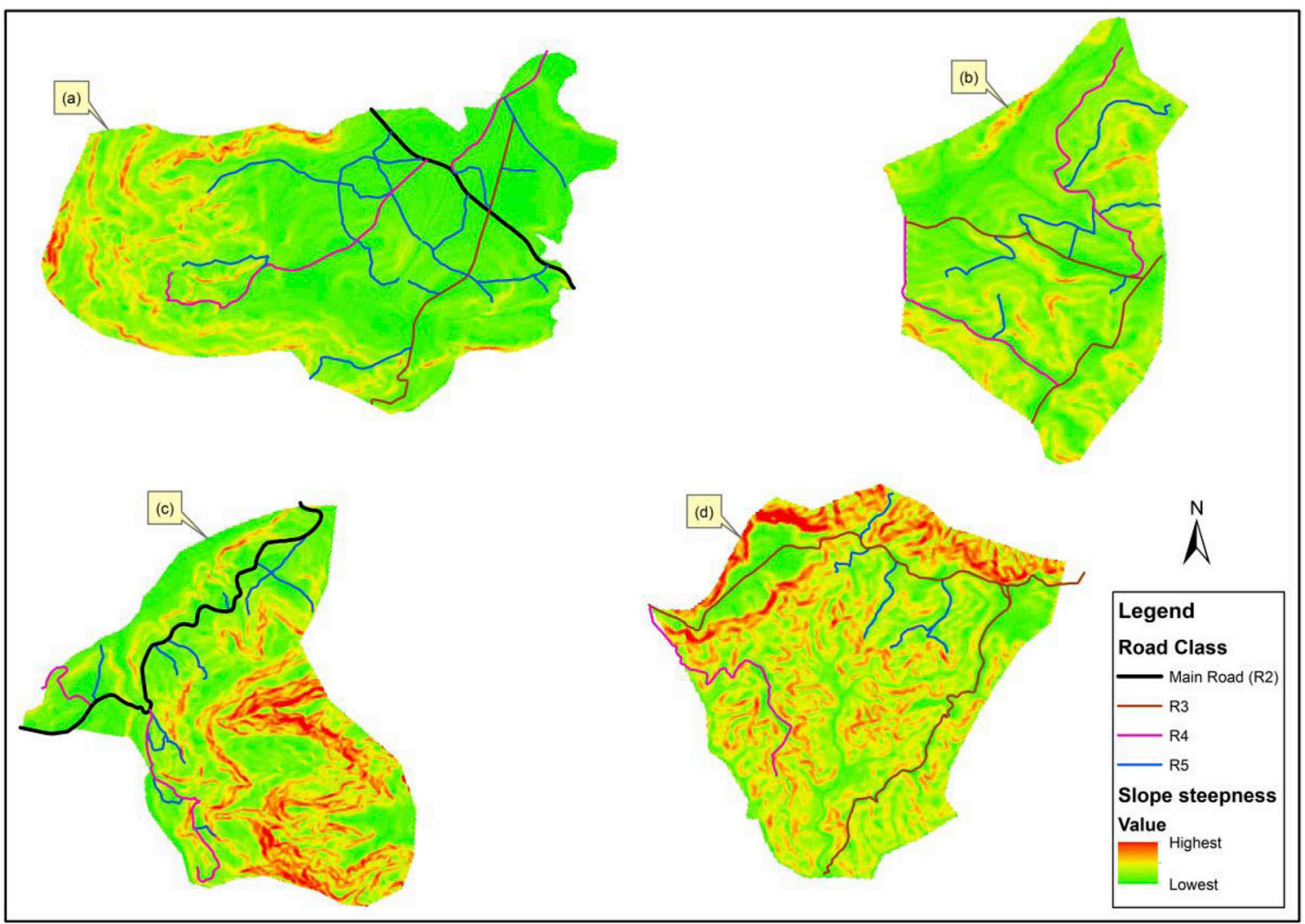

Fig. 5. The variation in slope gradient for the Dukuza (a), Emazabekweni (b), Mhlwazini (c) and Mkhunya (d).
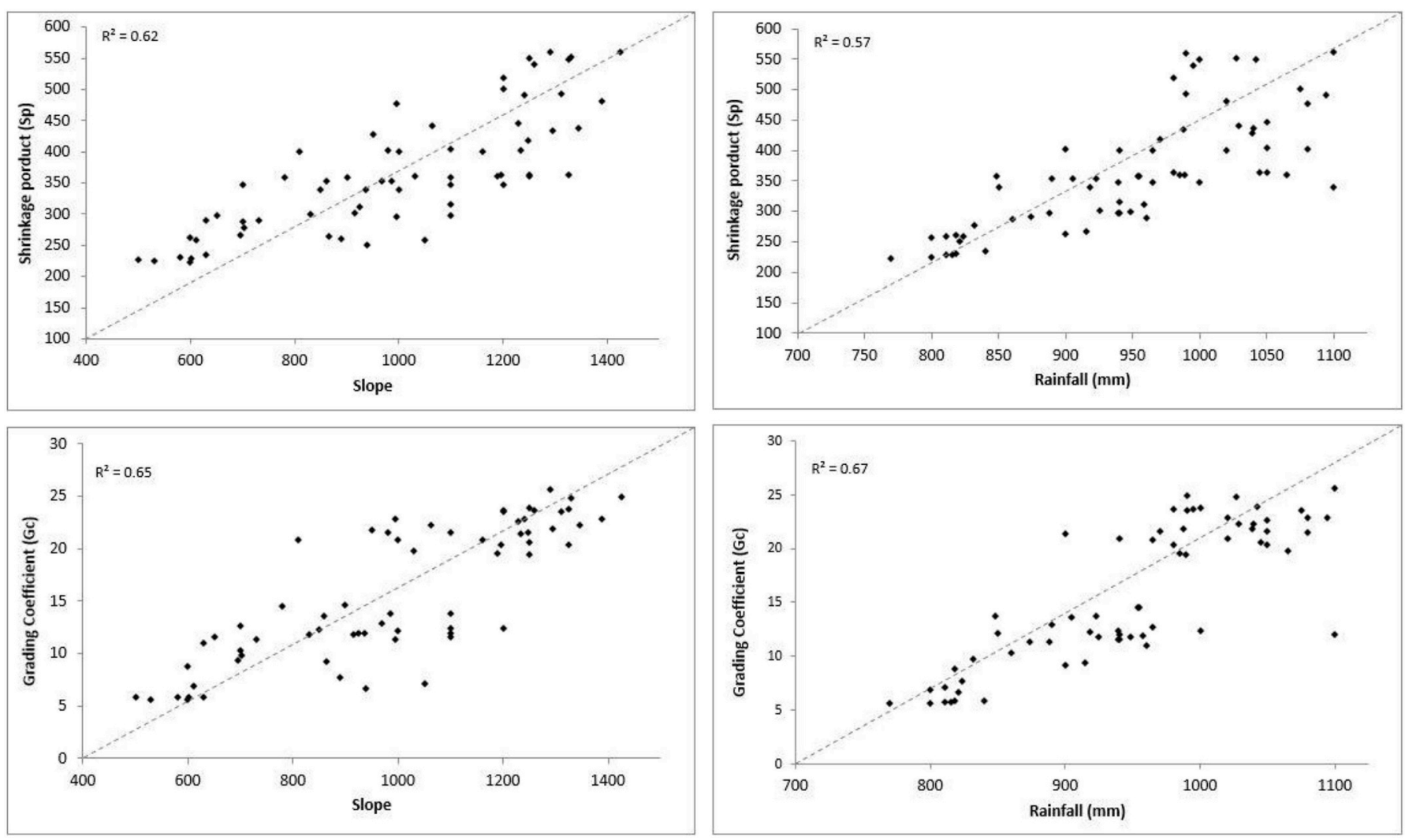

Fig. 6. The relationship between environmental variables (namely rainfall and slope) and shrinkage product and grading coefficient. 
selection reduces surface deterioration and maintenance costs on unpaved roads. Therefore, if all road classes in the Dukuza area were well designed, constructed and maintained, the rate and extent of surface deterioration is expected to be minimal. Terrain and rainfall do have a significant influence on surface material quality and hence the deterioration of the road surfaces in the four areas under study. Therefore, this accomplishes that regular monitoring of road conditions is conducive as an effective management strategy to limit the negative impacts that could result from the terrain and rainfall. Since, this study only assessed four areas with a limited number of wards; future research should focus on including more areas at municipal level for an in-depth analysis. In addition, more research needs to be conducted to investigate the role of engineering designs and construction methods on surface deterioration of on unpaved road networks.

Future studies may investigate the use of other environmental attributes that may improve the prediction of rural road deterioration. Furthermore, this study only used available rainfall and slope information; other studies may consider including aspects such asvegetation condition or soil variations to improve mapping predictions. Additionally, including current rainfall information and at finer resolution $(<1 \mathrm{~km})$ would provide more detailed information for areas with the potential of up scaling the methodology with improvement to provide information regionally or at a provincial level on road surface condition.

\section{Conclusions}

This study aimed to assess the surface material quality of unpaved rural roads in four rural areas in KwaZulu-Natal in order to understand susceptibility to surface deterioration. This study further establishes other possible factors (such as slope gradient and rainfall) that could determine road surface deterioration. Overall, the findings of this study have shown that material selection remains a common problem in most unpaved rural road networks. In this study, most of the road networks assessed have poor material quality, thus making them vulnerable to increased surface deterioration and maintenance costs. Although the level of surface deterioration was not assessed in this study, the results obtained suggest that material quality has the potential to affect the nature (rate and extent) of surface deterioration on unpaved road networks. For example, erodibility, dustiness, slipperiness and the formation of ravels and corrugations are factors which are indicative of surface deterioration as a result of poor material quality, and other external factors. Furthermore, this study was also able to establish that natural factors such as terrain and rainfall conditions could also play an important role on the nature of surface deterioration of unpaved road networks. Good material selection is therefore a prerequisite to reducing the contribution of the natural variables on surface deterioration of unpaved road networks. Overall, this study provided a framework for assessing road conditions of rural networks and their potential risk to slope and rainfall variabilities.

\section{Appendix A. Supplementary data}

Supplementary data to this article can be found online at https:// doi.org/10.1016/j.pce.2019.04.005.

\section{References}

AASHTO, 2007. Standard Method of Test for Determining the Liquid Limit of Soils. AASHTO Standard T89-07. American Association of State Highway and Transportation Officials (AASHTO), Washington, D.C.

AASHTO, T.90, 2010. Standard Method of Test for Determining the Plastic Limit and Plasticity Index of Soils, twentieth ed. Single User Digital Publication, American Association of State Highway and Transportation Officials, Washington, DC.

Alzubaidi, H., Magnusson, R., 2002. Deterioration and rating of gravel roads: state of the art. Road Mater. Pavement Des. 3 (3), 235-260.

Asher, S., Novosad, P., 2016. Market access and structural transformation: evidence from rural roads in India. In: Job Market Paper, January, 11, 2016.
ASTM C136, 2006. Standard Test Method for Sieve Analysis of Fine and Coarse Aggregates. ASTM International, West Conshohocken, Pa. www.astm.org.

Balaram, Y., Mostert, M., 2014. Lessons learnt from the measurement of gravel road roughness in Kwazulu-Natal. In: SARF/IRF Regional Conference, 5th, 2014, Pretoria, South Africa.

Booth, D., Hanmer, L., Lovell, E., 2000. Poverty and Transport. Report Prepared for the World Bank in Collaboration with DFID. Overseas Development Institute, United Kingdom.

Bryceson, D.F., 2002. The scramble in Africa: reorienting rural livelihoods. World Dev. 30, 725-739.

Buol, S.W., Southard, R.J., Graham, R.C., Mcdaniel, P.A., 2011. Soil Genesis and Classification. John Wiley \& Sons, United States of America.

Button, K., 2010. Transport Economics. Edward Elgar Publishing, Cheltenham, United Kingdom.

Calderon, C., Cantu, C., Chuhan-Pole, P., 2018. Infrastructure Development in Sub-saharan Africa: a Scorecard. The World Bank.

Chambers, R., Longhurst, R., Pacey, A., 1981. Seasonal Dimensions to Rural Poverty. Frances Pinter, United Kingdom.

Coffin, A.W., 2007. From roadkill to road ecology: a review of the ecological effects of roads. J. Transp. Geogr. 15, 396-406.

Committee For State Road Authorities, 1976. Standard Methods of Testing Road Construction Materials. Technical Methods for Highways; TMH 1. Department of Transport, Pretoria.

Committee of Transport Officials, 2012. TRH26 South African Road Classification and Access Management Manual, Version 1.0. , Accessed date: 2 May 2018.

Croke, J., Hairsine, P., 2006. Sediment delivery in managed forests: a review. Environ. Rev. 14, 59-87.

Dercon, S., 2006. Economic reform, growth and the poor: evidence from rural Ethiopia. J. Dev. Econ. 81, 1-24.

Escobal, J., Ponce, C., 2008. Enhancing Income Opportunities for the Rural Poor: the Benefits of Rural Roads. Economic Reform in Developing Countries. pp. 307.

Fan, S., Chan-Kang, C., 2005. Road Development, Economic Growth, and Poverty Reduction in China. International Food Policy Research Institute, United States of America.

Fan, S., Chan-Kang, C., 2008. Regional road development, rural and urban poverty: evidence from China. Transport Pol. 15, 305-314.

Farr, T.G., Kobrick, M., 2000. Shuttle radar Topography mission produces a wealth of data. EOS Transact. - Am. Geophys. Union 81, 583-585.

Fu, B., Newham, L.T., Ramos-Scharron, C.E., 2010. A review of surface erosion and sediment delivery models for unsealed roads. Environ. Model. Softw 25 (1), 1-14.

Furniss, M.J., Roelofs, T.D., Yee, C.S., 1991. Road Construction and Maintenance, vol. 19. American Fisheries Society Special Publication, pp. 297-323.

Gillies, J.A., Watson, J.G., Rogers, C.F., Dubois, D., Chow, J.C., Langston, R., Sweet, J., 1999. Long-term efficiencies of dust suppressants to reduce PM10 emissions from unpaved roads. J. Air Waste Manag. Assoc. 49 (1), 3-16.

Goosem, M., 2007. Fragmentation impacts caused by roads through rainforests. Curr. Sci. $1587-1595$.

Gucinski, H., 2001. Forest Roads: a Synthesis of Scientific Information. DIANE Publishing.

Hartley, A., 1974. A review of the geological factors influencing the mechanical properties of road surface aggregates. Q. J. Eng. Geol. 7, 69-100.

Hazell, P.B., Haggblade, S., 1990. Rural-urban Growth Linkages in India. World Bank Publications, United States of America.

Henning, T.F., Flockhart, G., Costello, S.B., Jones, V., Rodenburg, B., 2015. Managing Gravel Roads on the Basis of Fundamental Material Properties. Transportation Research Board, 94th Annual Meeting, Washington DC.

Hettige, H., 2006. When Do Rural Roads Benefit the Poor and How? an In-Depth Analysis Based on Case Studies. Asian Development Bank, Philippines.

Hodges, J.W., Rolt, J., Jones, T.E., 1975. The Kenya Road Transport Cost Study: Research on Road Deterioration. TRL Research Report LR673. Transport and Road Research Laboratory, Crowthorne.

Housing Development Agency, 2013. The Housing Development Agency Annual Report 2012/2013 [Online]. South Africa: HDA, Johannesburg, Accessed date: 4 October 2016.

Jacoby, H.G., 2000. Access to markets and the benefits of rural roads. Econ. J. 110, $713-737$.

Jones, T.E., 1984. The Kenya Maintenance Study on Unpaved Roads: Research on Deterioration. Overseas Unit, Transport and Road Research Laboratory, Kenya.

Jones, D., 1999. Holistic approach to research into dust and dust control on unsealed roads. Transport. Res. Rec.: J. Transportat. Res. Board (1652), 3-9.

Jones, L.D., Jefferson, I., 2012. Expansive Soils. ICE Publishing, United Kingdom, pp. 413-441.

Jones, D., Paige-Green, P., 2015. Limitations of using conventional unpaved road specifications for understanding unpaved road performance. Transport. Res. Rec.: J. Transportat. Res. Board 30-48.

Kachouri, S., Achour, H., Abida, H., Bouaziz, S., 2015. Soil erosion hazard mapping using Analytic Hierarchy Process and logistic regression: a case study of Haffouz watershed, central Tunisia. Arab. J. Geosci. 8, 4257-4268.

Keller, G., Sherar, J., 2003. Low-Volume Roads Engineering: Best Management Practices. Transportation Research Record: Journal of the Transportation Research Board, pp. 174-181 1819.

Kepe, T., Tessaro, D., 2014. Trading-off: rural food security and land rights in South Africa. Land Use Pol. 36, 267-274.

Lebo, J., Schelling, D., 2001. Design and Appraisal of Rural Transport Infrastructure: Ensuring Basic Access for Rural Communities. World Bank Publications, United Kingdom.

Leung, Y.F., Marion, J.L., 1996. Trail degradation as influenced by environmental factors: 
a state-of-the-knowledge review. J. Soil Water Conserv. 51 (2), 130-136.

Lishman, D., 2013. A Critical Evaluation of Road Pricing in South Africa. Dissertation, University of Cape, Town, South Africa.

Luce, C.H., Cundy, T.W., 1994. Parameter identification for a runoff model for forest roads. Water Resour. Res. 30, 1057-1069.

Lufumpa, C.L., Mubila, M., Yepes, T., 2017. Integrated Approaches for Infrastructure. Infrastructure in Africa: Lessons for Future Development. pp. 423.

Lugo, A.E., Gucinski, H., 2000. Function, effects, and management of forest roads. For. Ecol. Manag. 133, 249-262.

Madzikigwa, B., 2003. Nature and effects of low-volume roads in Botswana. Transportation research record: journal of the transportation research board 1819, 88-95.

Moloisane, R., Visser, A.T., 2014. Evaluation of the strength behaviour of unpaved road material treated with electrochemical-based non-traditional soil stabilisation additives. J. S. Afr. Inst. Civ. Eng. 56, 28-39.

Mucina, L., Rutherford, M.C., 2006. The Vegetation of South Africa, Lesotho and Swaziland, vol. 19 South African Biodiversity Institute, Pretoria, Strelitzia.

Musemwa, L., Muchenje, V., Mushunje, A., 2015. Household food insecurity in the poorest province of South Africa: level, causes and coping strategies. Food Security 7, 647-655.

Mwaipungu, R.R., Allopi, D., 2012. The appropriate material specifications and manual are key for effective gravel roads design, construction and maintenance practice. In: Practice' Proceedings of 1st National Conference on Intermodal Transportation: Problems, Practices, and Policies, pp. 176-188.

Njenga, P., Davis, A., 2003. Drawing the road map to rural poverty reduction. Transport Rev. 23 (2), 217-241.

Nkomo, S.L., Desai, S., Peerbhay, K., 2016. Assessing the conditions of rural road networks in South Africa using visual observations and field-based manual measurements: a case study of four rural areas in Kwa-Zulu Natal. Rev. Soc. Sci. 1 (2), 42-55.

Ozler, Berk, Hoogeveen, J.G.M., 2005. Not Separate, Not Equal: Poverty and Inequality in Post-Apartheid South Africa. William Davidson Institute Working Paper No. 739. Available at: SSRN: https://ssrn.com/abstract.

Paige, P., Netterberg, F., 1987. Requirements and properties of wearing course materials for unpaved roads in relation to their performance. Traffic 576, 625.

Paige-Green, P., 1989. New Performance-Related Specifications for Unpaved Roads. Annual Transportation Convention, Pretoria, South Africa 1989.

Paige-Green, P., 1999a. Geological factors affecting performance of unsealed road materials. Transport. Res. Rec.: J. Transportat. Res. Board (1652), 10-15.

Paige-Green, P., 1999b. Materials for sealed low-volume roads. Transport. Res. Rec.: J. Transportat. Res. Board (1652), 163-171.

Paige-Green, P., 2006. Appropriate Roads for Rural Access. Third Gulf Conference on Roads, CSIR Built Environment, South Africa.

Paige-Green, P., 2007a. Improved material specifications for unsealed roads. Q. J. Eng. Geol. Hydrogeol. 40 (2), 175-179.

Paige-Green, P., 2007b. New perspectives of unsealed roads in South Africa. Road Transp. Res.: J. Austral. N. Z. Res. Pract. 16 (3), 56.

Patel, N.R., 1984. Planning for rural roads in India. In: Brans, J.P. (Ed.), Operations Research. vol. 84. pp. 350-360.

Plessis-Fraissard, M., 2010. Rural Roads: the Wealth of Nations. International Road Federation. United States of America.

Porter, G., 2002. Living in a walking world: rural mobility and social equity issues in sub-
Saharan Africa. World Dev. 30 (2), 285-300.

Porter, G., 2007. Transport planning in sub-Saharan Africa. Prog. Dev. Stud. 7, 251-257.

Porter, G., 2014. Transport services and their impact on poverty and growth in rural subSaharan Africa: a review of recent research and future research needs. Transport Rev. 34, 25-45.

Qin, Y., Zhang, X., 2016. The road to specialization in agricultural production: evidence from rural China. World Dev. 77, 1-16.

Queiroz, C.A., Gautam, S., 1992. Road Infrastructure and Economic Development: Some Diagnostic Indicators, vol. 921 World Bank Publications, United Kingdom.

Ramos-Scharrón, C.E., Macdonald, L.H., 2007. Measurement and prediction of natural and anthropogenic sediment sources, St. John, US Virgin Islands. Catena 71, 250-266.

Ramos-Scharrón, C.E., Macdonald, L.H., 2005. Measurement and prediction of sediment production from unpaved roads, St John, US Virgin Islands. Earth Surf. Process. Landforms: J. Br. Geomorphol. Res. Group 30, 1283-1304.

Riverson, J., Carapetis, S., 1991. Intermediate Means of Transport in Sub-saharan Africa. World Bank technical paper, pp. 161.

Sati, V.P., Vangchhia, L., 2017. Sustainable livelihood approach to poverty reduction. In: A Sustainable Livelihood Approach to Poverty Reduction. Springer Briefs in Environmental Science. Springer, Cham.

Sessions, J., 2007. Forest Road Operations in the Tropics. Springer.

Shenggen, F., Zhang, X., 2004. Infrastructure and regional economic development in rural China. China Econ. Rev. 15, 203-214.

Smith, A., Visser, A.T., 2001. A South African Road Network Classification Based on Traffic Loading. M Eng project report, University of Pretoria.

Stanturf, J.A., Goodrick, S.L., Warren Jr., M.L., Charnley, S., Stegall, C.M., 2015. Social vulnerability and Ebola virus disease in rural Liberia. PLoS One 10, e0137208.

Starkey, P. (Ed.), 2002. Improving Rural Mobility: Options for Developing Motorized and Nonmotorized Transport in Rural Areas. World Bank Publications vol. 23.

Statistics South Africa, 2018. http://www.statssa.gov.za/?p=11341, Accessed date: 17 September 2018.

Technical Recommendations For Highways draft 20, 1990. Structural Design, Construction and Maintenance of Unpaved Roads. Committee of State Road Authorities, Pretoria, South Africa.

Teravaninthorn, S., Raballand, G., 2009. Transport Prices and Costs in Africa: a Review of the Main International Corridors. World Bank Publications, United Kingdom.

Trombulak, S.C., Frissell, C.A., 2000. Review of ecological effects of roads on terrestrial and aquatic communities. Conserv. Biol. 14, 18-30.

Wagstaff, A., 2004. The Millennium Development Goals for Health: Rising to the Challenges. World Bank Publications.

Wemple, Bc, Browning, T., Ziegler, Ad, et al., 2018. Ecohydrological disturbances associated with roads: current knowledge, research needs, and management concerns with reference to the tropics. Ecohydrology 11, e1881.

Wilkie, D., Shaw, E., Rotberg, F., Morelli, G., Auzel, P., 2000. Roads, development, and conservation in the Congo Basin. Conserv. Biol. 14 (6), 1614-1622.

Ziegler, A.D., Giambelluca, T.W., 1997. Importance of rural roads as source areas for runoff in mountainous areas of northern Thailand. J. Hydrol 196, 204-229.

Ziegler, A.D., Giambelluca, T.W., Sutherland, R.A., 2001. Horton overland flow contribution to runoff on unpaved mountain roads: a case study in northern Thailand. Hydrol. Process. 15, 3203-3208. 